\title{
Dynamics of Sulfonylurea-Induced Insulin Release from the Isolated Perfused Rat Pancreas ${ }^{*}$
}

\author{
C. F. Gotfredsen \\ Department of Pharmacology, NOVO Industri A/S, Bagsvaerd, Denmark
}

Summary. In the isolated perfused rat pancreas various sulfonylurea drugs were tested with a basal glucose level of $1 \mathrm{mg} / \mathrm{ml}$ in the perfusion buffer and were found to cause a biphasic insulin response. NOVOCS 476, a new and potent sulfonylurea, and glibenclamide qualitatively differed from tolbutamide, glibornuride, glipizide, and glisoxepide, which were all alike in terms of the relationship between first and second phases of insulin release.

Key words: Insulin secretion, rat pancreas perfusion, NOVO CS 476, sulfonylureas.

With the recent introduction of potent sulfonylureas discussion has arisen whether all of these drugs stimulate insulin release in a similar way or if the so-called second generation sulfonylureas possess both a higher potency on a weight basis and a different profile of B-cell stimulation $[1,8,19,20]$.

In the present study glibenclamide, glibornuride, glipizide, and glisoxepide have been compared with tolbutamide with respect to their effect on insulin release from the isolated perfused rat pancreas. This work also includes a new hypoglycaemic sulfonylurea synthesized in our laboratories, NOVO CS 476 , chemically $\mathrm{N}$-[4-(2-(2,3-dihydrobenzo (b) furan-7carboxamido)-ethyl)-benzene sulphonyl]- $\mathrm{N}^{\prime}$-cyclohexylurea, a compound with blood glucose lowering effect of similar potency to glibenclamide both in experimental animals [15] and in man.

\footnotetext{
* Presented in part at the Sixth International Congress of Pharmacology, Helsinki, July 1975
}

\section{Materials and Methods}

Male Wistar rats, NOVO strain, weighing 230-265 g, with access to food and water ad libitum, were anaesthetized with $\mathrm{Nembutal}^{\circledR} 40 \mathrm{mg}$ per $\mathrm{kg}$ body weight intraperitoneally, and the pancreas was removed by the technique of Sussmann et al. [22] as modified by A. J. Moody (personal communication).

By this procedure the arterial cannula was placed in the abdominal aorta just proximal to the renal arteries and the perfusion started as the aorta was tied off at the diaphragm level to avoid anoxia. The operation lasted 35-40 min. Various technical failures or lack of glucose response after two hours perfusion resulted in a success rate of approximately $60 \%$.

\section{Perfusion}

Perfusions were carried out in an Ambec 1000 perfusion apparatus, set at $38^{\circ} \mathrm{C}$, and at a constant flow of $2.5 \mathrm{ml} / \mathrm{min}$, which resulted in an arterial perfusion pressure of 30-60 mm Hg during 20-120 min.

The perfusion buffer was: Earle's Balanced Salt Solution, $25 \mathrm{mM}$ HEPES, and penicillin and streptomycin 100 I.U./ml each, (Flow Laboratories), 5 $\mathrm{g} / 100 \mathrm{ml}$ Dextran T70 (Pharmacia), and $4 \mathrm{~g} / 100 \mathrm{ml}$ human albumin (KABI), treated with charcoal and dialysed 5 times against distilled water [5]. The concentration of glucose was 1.0 or $1.5 \mathrm{mg} / \mathrm{ml}$. The $\mathrm{pH}$ was adjusted to 7.4 with sodium hydroxide.

The perfusion buffer was equilibrated with pure oxygen. This resulted in a partial pressure of oxygen of $300-450 \mathrm{~mm} \mathrm{Hg}$ in the arterial cannula. In the venous effluent the partial pressure was $100-150 \mathrm{~mm} \mathrm{Hg}$.

Perfusate was not sampled during the first $20 \mathrm{~min}$ of perfusion. Infusions of glucose or sulfonylureas at a rate of $0.1 \mathrm{ml} / \mathrm{min}$ into the arterial line followed the time schedule given in Figure 1. 

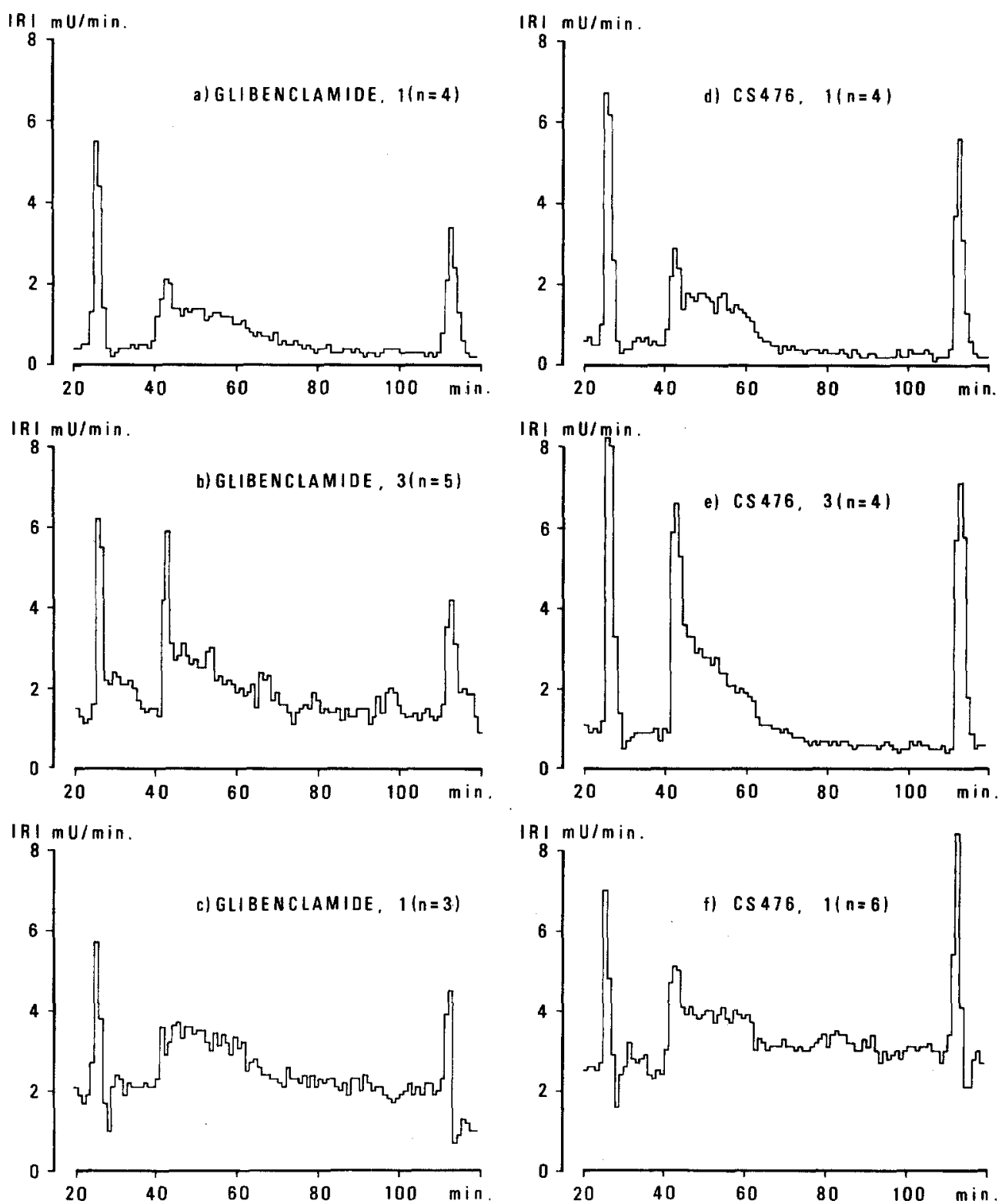

Fig. 1 a-f. Insulin release from the isolated perfused rat pancreas. Test glucose infusions reaching $3 \mathrm{mg}$ glucose/ml buffer were carried out at 25-26 and 111-112 min. Basal buffer glucose level was $1.0 \mathrm{mg} / \mathrm{ml} \mathrm{in} \mathrm{a),} \mathrm{b),} \mathrm{d),} \mathrm{and} \mathrm{e)} \mathrm{and} 1.5 \mathrm{mg} / \mathrm{ml}$ in c), and f). At 41-60 min the following substances were infused to give the calculated concentrations in the perfusate as stated: a) glibenclamide $1 \mathrm{mg} / \mathrm{l}, \mathrm{b}$ ) glibenclamide $3 \mathrm{mg} / 1, \mathrm{c}$ ) glibenclamide $1 \mathrm{mg} / 1$, d) NOVO CS $4761 \mathrm{mg} / \mathrm{l}$, e) NOVO CS $4763 \mathrm{mg} / \mathrm{l}$, and f) NOVO CS $4761 \mathrm{mg} / 1$. Mean values are given for the number of perfusions shown in parentheses

\section{Analysis and Data Handling}

Samples were kept frozen until analysed for insulin by immunoassay according to Heding [11]. Standards were made up of rat insulin, 22.7 I.U./mg (bioassay, mice), in the perfusion buffer. ${ }^{125} \mathrm{I}$-rat insulin and antipork insulin serum (guinea pig) were diluted with phosphate-albumin-merthiolate buffer. Samples were analysed singly, standards $(0-160 \mu \mathrm{U}$ per tube) in quaduplicate.

Insulin release rate is given in $\mathrm{mU} / \mathrm{min}$ in the figures. Net insulin release to the 2 min glucose infusions and to the test compounds, divided in a first and a second phase, was calculated from the basal level during 31-40 min or during 101-110 min for the last glucose test if the two base levels were different (Student's t-test, $\mathrm{p}<0.01$ ).

\section{Results}

Insulin release rate from the perfused pancreas after a twenty minute stimulation with glibenclamide or 
Table 1. First and second phase net insulin release after sulfonylurea infusions to the perfused rat pancreas in the presence of glucose $1 \mathrm{mg} / \mathrm{ml}$ compared with the mean net insulin release to test glucose infusions at 25-26 and 111-112 minutes and with the basal insulin secretion rate at $31-40$ minutes. Calculated concentrations in the perfusate of the sulfonylureas used are stated. Mean values $\pm S$ EM for the net release during the two sampling periods are given

\begin{tabular}{|c|c|c|c|c|c|c|}
\hline \multirow[b]{2}{*}{ Drug } & \multirow[b]{2}{*}{$\begin{array}{l}\text { Conc. } \\
\mathrm{mg} / \mathrm{l}\end{array}$} & \multirow[b]{2}{*}{$\mathrm{N}$} & \multicolumn{2}{|c|}{ 1st phase (42-44 min.) } & \multicolumn{2}{|c|}{ 2nd phase $(45-60 \mathrm{~min})}$. \\
\hline & & & Net IRI mU & $\begin{array}{l}\% \text { of net IRI of } \\
\text { glucose tests }\end{array}$ & Net IRI mU & $\begin{array}{l}\% \text { over basal } \\
\text { IRI release }\end{array}$ \\
\hline Tolbutamide & 100 & 3 & $10.1 \pm 1.2$ & 107 & $13.6 \pm 1.9$ & 90 \\
\hline Glibornuride & 5 & 4 & $11.1 \pm 1.7$ & 120 & $10.4 \pm 1.9$ & 146 \\
\hline Glipizide & 5 & 4 & $14.4 \pm 4.5$ & 103 & $12.6 \pm 3.0$ & 108 \\
\hline Glisoxepide & 5 & 5 & $16.2 \pm 2.9$ & 93 & $21.4 \pm 5.0$ & 157 \\
\hline Glibenclamide & 1 & 4 & $4.3 \pm 0.6^{\mathrm{a}}$ & 50 & $12.6 \pm 3.5^{\mathrm{b}}$ & 196 \\
\hline Glibenclamide & 3 & 5 & $9.8 \pm 3.9$ & 95 & $17.4 \pm 4.5^{\mathrm{b}}$ & 82 \\
\hline NOVO CS 476 & 1 & 4 & $5.8 \pm 1.9$ & 46 & $15.4 \pm 9.2$ & 186 \\
\hline NOVO CS 476 & 3 & 4 & $15.1 \pm 2.8$ & 90 & $24.9 \pm 1.5^{\mathrm{c}, d}$ & 193 \\
\hline
\end{tabular}

${ }^{a}$ vs. tolbutamide, Student's $t$-test, $\mathrm{p}<0.05$

${ }^{\mathrm{b}}$ vs. 1st phase, paired $t$-test, $\mathrm{p}<0.05$

${ }^{\circ}$ vs. 1st phase, paired $t$-test, $\mathrm{p}<0.01$

${ }^{d}$ vs. tolbutamide, Student's $t$-test, $\mathrm{p}<0.01$

NOVO CS 476 showed a biphasic pattern with minimal tailing (Fig. 1) and net insulin release was calculated separately for the first 2-4 minutes and the last 5-20 minutes (Table 1). Increasing the arterial concentration of the two sulfonylureas from $1 \mathrm{mg} / \mathrm{l}$ to 3 $\mathrm{mg} / \mathrm{l}$ made the first phase more pronounced. In contrast, perfusions in the presence of $1.5 \mathrm{mg}$ glucose $/ \mathrm{ml}$ of buffer with $1 \mathrm{mg} / 1$ of glibenclamide showed very little first phase secretion, whereas the second phase insulin release was the same at the two glucose concentrations for both glibenclamide and NOVO CS 476. Twenty minute blank infusions did not change basal insulin secretion rate at either glucose concentration.

Figure 1 also shows the brisk insulin release to the two glucose infusions of 2 minutes duration used as a test of viability. In separate experiments a 20 minute glucose infusion at a concentration of $3 \mathrm{mg} / \mathrm{ml}$ resulted in a biphasic insulin release with a second phase release rate $6-7$ times higher than the basal rate at 1 $\mathrm{mg}$ glucose $/ \mathrm{ml}$, or $2-3$ times higher than at $1.5 \mathrm{mg} / \mathrm{ml}$.

Tolbutamide, glibornuride, glipizide, and glisoxepide were tested in perfusions with $1 \mathrm{mg}$ glucose $/ \mathrm{ml}$ of buffer in the concentrations stated in Table 1. Qualitatively the insulin response after these sulfonylureas differed little from that after NOVO CS 476 at $3 \mathrm{mg} / 1$ (Fig. 1e), i.e. a significant first phase and a slowly declining second phase insulin secretion. However, both glibenclamide and NOVO CS 476 caused significantly less insulin release during the first phase than during the second phase secretion in contrast to the other drugs tested.

\section{Discussion}

Sulfonylureas stimulate insulin release from the perfused pancreas in the absence of glucose. However, in such preparations only a single phase of few minutes duration can be observed $[6,8,16,18]$. When glucose is present a biphasic insulin release has been shown to result from the infusion of tolbutamide $[18,20,23]$, glibornuride $[8,16,20]$, and glipizide $[1,23]$. Tolbutamide evidently increases the sensitivity of the B-cells towards glucose, indicated by a shifting of the sigmoidal glucose dose-response curve to the lower concentrations $[3,18]$.

Part of the tolbutamide effect is very direct since insulin release is stimulated $1-1^{1 / 2}$ min. earlier with tolbutamide than with glucose $[2,17]$. This is certainly a direct effect on the B-cell plasma membrane since tolbutamide covalently linked to dextran particles can elicit insulin release [4]. Generally, the binding of sulfonylureas to B-cells from obob mice is directly related to the biological activity of the drugs and, as a competition phenomenon, is inversely related to the medium albumin concentration [12, 13, 14, 21, 24].

Direct evidence for a similar binding activity relationship in the perfused rat pancreas does not exist. However, the suppressive influence of the medium albumin concentration on the insulin releasing activity and the "tailing" effect of different sulfonylureas supports the hypothesis $[1,7,8,16,19]$.

In the present study, glibenclamide and to some extent NOVO CS 476 showed weak tailing effects at $4 \%$ albumin in the perfusion buffer, whereas tol- 
butamide, glibornuride, glipizide, and glisoxepide showed no tailing.

Both glibenclamide and NOVO CS 476 differed from the other sulfonylureas tested in causing a significant second phase insulin release with only a minor stimulation of the first phase secretion. This first phase secretion was found to be more significant at the concentration of $3 \mathrm{mg} / 1$ of the compounds. In contrast glibenclamide caused an insignificant first phase insulin release at $1.5 \mathrm{mg}$ glucose per $\mathrm{ml}$, as described previously $[18,19]$.

The significance of the first phase insulin release is obscure, since it can be stimulated in the absence of glucose and only by sudden concentration changes [6]. Further it is not correlated to the in vivo potency of the sulfonylureas, since glibenclamide was less active than glibornuride and only sixteen times as active as tolbutamide by this criterion [8].

The ability to stimulate the first phase insulin secretion distinguishes glibenclamide and NOVO CS 476 from glibornuride, glisoxepide, glipizide, and tolbutamide. In vivo this is substantiated by the lack of an early insulin peak in peripheral plasma after equipotent hypoglycemic doses of glibenclamide and NOVO CS 476 in contrast to tolbutamide in dogs [15] and of glibenclamide, in contrast to glibornuride, glisoxepide, and tolbutamide, in humans [23, 24]. The full clinical significance of this difference awaits further elucidation.

Acknowledgements. We thank Dr. A. J. Moody for having shown us the modified pancreas perfusion techniques and for stimulating discussion. Miss Susanne Jespersen, Mrs. Marianne Nielsen, and Mrs. Inge Birgit Joergensen are thanked for their skilful technical assistance during these studies.

\section{References}

1. Artini, D., Abbiati, R., Orsini, G., Parenti, M. A., Bloch, K., Daturi, S., Mandelli, V.: Pharmacodynamic aspects of two sulphonylurea derivatives glipizide and glibenclamide, Diabetologia 9 (Suppl.), 311-316 (1973)

2. Bennett, L. L., Curry, D. L., Curry, K.: Differences in insulin release in response to glucose and tolbutamide stimulation. Proc. Soc. exp. Biol. (N. Y.) 144, 436-439 (1973)

3. Bosboom, R. S., Zweens, J., Bouman, P. R.: Effects of feeding and fasting on the insulin secretory response to glucose and sulfonylureas in intact rats and isolated perfused rat pancreas. Diabetologia 9, 243-250 (1973)

4. Bowen, V., Lazarus, N. R.: Insulin release from the perfused rat pancreas. Mode of action of tolbutamide. Biochem. J. 142, 385-389 (1974)

5. Chen, R. F.: Removal of fatty acids from serum albumin by charcoal treatment. J. biol. Chem. 242, 173-181 (1967)

6. Curry, D. L.: Insulin secretory dynamics in response to slowrise and square-wave stimuli. Amer. J. Physiol. 221, 324-328 (1971)

7. Grodsky, G. M., Curry, D. L., Landahl, H., Bennett, L. L.: Further studies on the dynamic aspects of insulin release in vitro with evidence for a two-compartmental storage system. Acta diabet. lat. 6 (Suppl. 1), 554-579 (1969)
8. Grodsky, G. M., Lee, J., Fanska, R., Smith, D.: Insulin secretion from the in vitro perfused pancreas of the rat: Effect of Ro 6-4563 and other sulfonylureas. In: Recent hypoglycemic sulfonylureas, pp. 83-94. Bern: Hans Huber 1971

9. Haupt, E., Köberich, W., Beyer, J., Schöffling, K.: Pharmacodynamic aspects of tolbutamide, glibenclamide, glibornuride and glisoxepide. 1. Dose response relations and repeated administration in diabetic subjects. Diabetologia 7, 449-454 (1971)

10. Haupt, E., Köberich, W., Beyer, J., Schöffling, K.: Pharmacodynamic aspects of tolbutamide, glibenclamide, glibornuride and glisoxepide. II. Repeated administration in combination with glucose. Diabetologia 7, 455-460 (1971)

11. Heding, L. G.: Determination of total serum insulin (IRI) in insulin-treated diabetic patients. Diabetologia 8, 260-266 (1972)

12. Hellman, B.: Potentiating effects of drugs on the binding of glibenclamide to pancreatic beta cells. Metabolism 23, 839-846 (1974)

13. Hellman, B.: Factors affecting the uptake of glibenclamide in microdissected pancreatic islets rich in $\beta$-cells. Pharmacology (Basel) 11, 257-267 (1974)

14. Hellman, B., Sehlin, J., Täljedal, I.-B.: The pancreatic $\beta$-cell recognition of insulin secretagogues. Islet uptake of sulfonylureas. Diabetologia 9, 210-216 (1973)

15. Joergensen, K. D.: The pharmacology of a new hypoglycaemic agent. N-[4-(2-(2,3-dihydrobenzo (b) furan-7-carboxamido)ethyl)-benzenesulphonyl]-N'-cyclohexylurea (NOVO CS 476). Acta pharmacol. (Kbh.), (in press 1976)

16. Laube, H., Fussgänger, R. D., Schröder, K. E., Pfeiffer, E. F.: Der Einfluß eines neuen Sulfonylharnstoffes auf die Insulinund Glucagonsekretion des isolierten perfundierten Pankreas. Arzneimittel-Forsch. 22, 2186-2188 (1972)

17. Lenzen, S.: The immediate insulin secretory response of the isolated rat pancreas to tolbutamide and glucose. FEBS Letters 49, 407-408 (1975)

18. Loubatieres, A., Mariani, M. M., Chapal, J.: Insulinosécrétion étudiée sur le pancréas isolé et perfusé du rat: I. Synergie entre glucose et sulfamides hypoglycémiants. Diabetologia 6, $457-466$ (1970)

19. Loubatieres, A., Mariani, M. M., Ribes, G., Alric, R.: Pharmacological comparison between tolbutamide and two second generation hypoglycemic sulfonylureas (glibenclamide and glisoxepide). Acta diabet. lat. 10, 261-281 (1973)

20. Pfeiffer, E. F., Fussgänger, R., Hinz, M., Katsilambros, N., Laube, H.: Dynamics of insulin and glucagon secretion of the isolated perfused rat pancreas and islets following and in presence of newer sulfonylureas. In: Recent hypoglycemic sulfonylureas, pp. 97-113. Bern: Hans Huber 1971

21. Sehlin, J.: Evidence for specific binding of tolbutamide to the plasma membrane of the pancreatic $\beta$-cells. Acta diabet. lat. 10, 1052-1060 (1973)

22. Sussman, K. E., Vaughan, G. D., Timmer, R. F.: An in vitro method for studying insulin secretion in the perfused isolated rat pancreas. Metabolism 15, 466-476 (1966)

23. Tasaka, Y., Sekine, M., Sugimoto, C., Ohgawara, H., Shizume, K.: Effect of glipizide on the release of insulin in the perfused rat pancreas in vitro. Endocr. jap. 21, 279-281 (1974)

24. Täljedal, I.-B.: Uptake of glibornuride by microdissected pancreatic islets. Hormone Res. 5, 211-216 (1974)

Received: December 29, 1975, and in revised form: April 29, 1976

Dr. C. F. Gotfredsen

Dept. of Pharmacology

NOVO Industri $\mathrm{A} / \mathrm{S}$

Novo Allé

DK-2880 Bagsvaerd

Denmark 